\title{
HEALING ARTS
}

\section{Materia Medica}

\section{It Was a Dark and Stormy Night}

\author{
Allan S. Detsky, MD, PhD, $C M^{1,2}$
}

${ }^{1}$ Insitute for Health Policy and Evaluation, and Department of Medicine, University of Toronto Toronto, Ontario, Canada; ${ }^{2}$ Department of Medicine, Sinai Health System and University Health Network Toronto, Ontario, Canada.

A pril, 1979; near the end of my internship year. I was on night call for medicine. Starting around $9 \mathrm{pm}$, we heard the following overhead announcement: "Doctor Leaf, Doctor Alex Leaf. Please call the Emergency Department." The other residents and I laughed. It was Friday night and Dr. Leaf was the Chair of the Department. While many of the physicians stayed until late in the night to round on their private patients, it was unlikely that he was in the hospital. At that hour, I imagined him sitting in front of a fireplace in his home on the North Shore, sipping sherry and reading manuscripts or grant applications. The announcement was repeated about 10 times up to midnight when it finally stopped.

Dr. Leaf was a quiet mild mannered man; bald, short, and slender. He was 58 at the time, which seemed very old to me then. He spoke softly, and used words sparingly. In some ways, it was hard to imagine him as Chair of Medicine, a department filled with very accomplished scientists, teachers, and clinicians, with some egos to match. He seemed so gentle. But we imagined that he must be very tough underneath. He was my attending physician earlier in the year; we called them "visits" in those days, short for visiting physician. That was an appropriate term because most of them only visited the service for one month a year. It wasn't until I was an attending physician years later that I realized that it is not easy to maintain competence with such infrequent experience and low volumes. But back then, we thought the faculty knew everything.

At our hospital, everyone was on a first name basis; we called the staff physicians by their first names no matter how senior they were. Ed Bland, a cardiologist, was over 80; still everyone called him Ed. But we weren't sure what to do when the Chair was our visit and started by calling him Dr. Leaf, as we had done before. In a quiet manner, he corrected us by saying, "Call me Alex". And so we did. He was a nephrologist. He knew a lot about electrolyte metabolism. He later went on to work with Physicians for Social Responsibility, speaking and writing about the hazards of nuclear war and climate change ${ }^{1}$. I regret that we never asked him to talk about that when we knew him.

But one time during the month he supervised our team, I phoned him in the middle of the night to review a clinical decision I was about to make. I suspected that a patient may

Received March 23, 2020

Revised March 23, 2020

Accepted August 5, 2020

Published online August 17, 2020 have a pulmonary embolus and wanted to order a pulmonary angiogram right away. For some reason, I wasn't comfortable making that decision without running it by him. We almost never called the visits at night for help; to my memory, it was the only time I did so in the 2 years I was a resident there. So I was a bit nervous. I started the conversation with, "I am sorry to bother you." He replied, "You are not bothering me, this is what I'm here for." I reviewed the case and he quickly agreed with my plan.

Around 5 am on that dark and stormy night, I was asleep in the call room when my fellow intern Pam Hartzband paged me. She was working the "minor med" desk; a place where patients with minor problems were sent by the Emergency Department triage nurse after listening to their stories. Minor med was a sea of humanity on a Friday night — lots of colds and back pain. It was unusual for a patient to be admitted from there to the ward. Pam started by saying, "I have an interesting patient for you". A 35-year-old man had driven down from Maine to our hospital in Boston after 6 weeks of right lower quadrant pain. He had been seen by several physicians in Maine and New Hampshire, and had even undergone an appendectomy because of this pain - his appendix was found to be normal. He was frustrated because the pain was still present weeks later and no one knew what was wrong with him. His father had done some research and found that our hospital was one of the "best" in New England. So they drove 5 hours, presented to the Emergency Department, and asked the triage nurse if they could see the "Chief of Medicine", assuming he must be the best doctor. Hence the overhead announcements. When Dr. Leaf didn't call back after several hours, he was sent to the minor med desk with a chief complaint of "chronic abdominal pain", where Pam finally saw him around midnight. She requested an abdominal X-ray which showed an oblong opacity over his spine that spanned from his neck to his sacrum. She wasn't sure what the diagnosis was, but she was sure it was serious. By the time I got there, his temperature was measured at 102 Fahrenheit. A few hours later, blood cultures grew staph aureus, and the diagnosis was a very large epidural abscess. His right lower quadrant pain was referred; caused by nerve entrapment from the abscess. On further questioning, we discovered he had documented staph aureus bacteremia about 2 months earlier that

J Gen Intern Med 35(12):3713-4

DOI: $10.1007 / \mathrm{s} 11606-020-06116-2$

(c) Society of General Internal Medicine 2020 
had been treated with 2 weeks of oral antibiotics; clearly not the right treatment. In those days, there was no interventional radiology to drain the abscess and the surgeons deferred surgery as they felt it was too risky. He was wrapped in a full body cast that went from the top of his neck to his knees (immobilization was felt to be a component of treating abscesses) and received 6 weeks of intravenous cloxacillin. He was cured.

I learned a valuable clinical lesson from this patient; one that stuck with me forever: chronic localized pain plus persistent fever equals bacterial abscess until proven otherwise. The lesson was next applied 20 years later when a 35-year-old woman presented to our hospital with severe leg pain and allodynia. She had been to 3 other hospitals and received pain medication but no diagnosis. Her friend told her to handcuff herself to the bed of the next hospital and refuse to leave until they figure out what is wrong. She exhibited a bizarre symptom; any time someone lightly brushed the skin on her leg, she screamed in pain. "Pull my leg, pull my leg." Her husband would then pull her leg and she would relax. The residents who told me about her the next morning thought she was faking and seeking pain medication. But when I asked about fever, the patient told us about drenching night sweats occurring for the past month. We obtained blood cultures that also grew staph aureus, and imaging revealed an epidural abscess in her lumbar spine; this time, the patient underwent surgical drainage and received a long course of intravenous antibiotics.

Dr. Leaf never saw the man from Maine who came looking for him on that dark and stormy night. Instead, he ended up with 2 interns, me and Pam. But Dr. Leaf taught me a different valuable lesson on that other night when I called him, one that also stuck with me over the years and helped me become a better attending physician. I teach a writing course where my advice is filled with many "do's and dont's". A few years ago, one student, a surgeon, told me that she could tell I was having an effect on her because she could hear the sound of my voice when I wasn't even there. She was in the operating room about to make a surgical decision and she heard me say "Don't do it!" She changed her mind. I too hear the sound of my teachers' voices. To this day, when residents call me in the middle of the night for advice and direction, they often say "I am sorry to bother you." And then I hear myself say, "You are not bothering me, this is what I'm here for."

Acknowledgments: I thank Raphael Rush, MD (University of
Toronto), and Pam Hartzband, MD (Harvard Medical School), for their
comments on an earlier draft. Neither was compensated for doing so.

Corresponding Author: Allan S. Detsky, MD, PhD, CM; Department of Medicine, Sinai Health System and University Health Network Toronto, Ontario, Canada (e-mail: Allan.Detsky@sinaihealth.ca).

\section{Compliance with Ethical Standards:}

Conflict of Interest: The author declares that he does not have a conflict of interest.

\section{REFERENCE}

1. Dunk JH, Jones DS. Sounding the alarm on climate change, 1989 and 2019. N Engl J Med. 2020; 382(3): 205-6.

Publisher's Note Springer Nature remains neutral with regard to jurisdictional claims in published maps and institutional affiliations. 